\title{
Evaluation of anthelmintic activity of liquid waste of Agave sisalana (sisal) in goats
}

\author{
Avaliação da atividade anti-helmíntica do resíduo líquido de Agave sisalana (sisal) em caprinos \\ Luciana Ferreira Domingues*; Mariana Borges Botura ${ }^{1}$; Ana Carla Ferreira Guedes da Cruz ${ }^{1}$; Cristiane Carina Yuki ${ }^{1}$; \\ Gisele Dias da Silva ${ }^{1}$; Márcia Silva Costa ${ }^{1}$; Gleeson Murphy²; Eduardo Luiz Trindade Moreira'; \\ Íris Daniela Santos de Meneses ${ }^{1}$; Maria das Graças Ávila Ribeiro de Almeida ${ }^{1}$; Alexsandro Branco ${ }^{3}$; \\ Maria Angela Ornelas de Almeida ${ }^{1}$; Maria José Moreira Batatinha ${ }^{1}$
}

${ }^{1}$ Escola de Medicina Veterinária, Universidade Federal da Bahia - UFBA

${ }^{2}$ Analytical Toxicology Division, United States Army Medical Research Institute of Chemical Defense - USAMRICD

${ }^{3}$ Faculdade de Ciências Farmacêuticas, Universidade Estadual de Feira de Santana - UEFS

Received July 12, 2010

Accepted August 3, 2010

\begin{abstract}
It was evaluated the anthelmintic activity of Agave sisalana (sisal) juice against gastrointestinal nematodes and its potential toxic effects in goats. In vitro tests showed more than $95 \%$ reduction in larval counts of the genus Haemonchus spp. at concentrations between 86.5 and $146.3 \mathrm{mg} . \mathrm{mL}^{-1}$. In vivo the percent reduction of larvae of the fourth (L4) and fifth (L5) stages of Haemonchus, Oesophagostomum and Trichostrongylus was less than 95\% in groups GI and GII, and between 80 and $90 \%$ in group GIII. A. sisalana juice at the concentrations tested in vitro was effective against gastrointestinal nematodes in goats; however, its anthelmintic efficacy was reduced when administered to animals.
\end{abstract}

Keywords: Agave sisalana, anthelmintic, goats, nematodes, sisal.

\section{Resumo}

Foi avaliada a atividade anti-helmíntica do suco de Agave sisalana (sisal) contra nematódeos gastrintestinais e possíveis efeitos tóxicos em caprinos. Nos testes in vitro, encontrou-se redução superior a $95 \%$ na contagem de larvas do gênero Haemonchus spp. nas concentraçóes entre 86,5 e $146,3 \mathrm{mg} \cdot \mathrm{mL}^{-1}$. In vivo, o percentual de reduçáo de larvas de quarto (L4) e quinto (L5) estágios de Haemonchus, Oesophagostomum e Trichostrongylus foi inferior a 95\% para o GI e GII, e entre 80 e $90 \%$ para o GIII. O suco de $A$. sisalana nas concentraçôes testadas in vitro foi efetivo contra nematódeos gastrintestinais de caprinos, apresentando, no entanto, reduzida eficácia anti-helmíntica quando administrado nos animais.

Palavras-chave: Agave sisalana, anti-helmíntico, caprinos, nematódeos, sisal.

The goat industry is a livestock activity of great socioeconomic importance in Northeastern Brazil, but its operation has been limited by frequent gastrointestinal nematode infections (GNI) and inappropriate drug use, which has led to resistance of these parasites to common anthelmintics.

Given the interest in the use of waste liquid of $A$. sisalana and lack of scientific evidence regarding its potential anthelmintic activity, the objective of the present study was to evaluate the effect of $A$. sisalana juice against gastrointestinal nematodes and its potential toxic effects in goats.

Agave sisalana plants were collected in Valente, Bahia. They were identified by botanists and voucher specimens (No. 838)

\footnotetext{
${ }^{*}$ Corresponding author: Luciana Ferreira Domingues

Escola de Medicina Veterinária, Universidade Federal da Bahia - UFBA

Rua Luiz Gama, n 7-07, Independência, CEP 17054-300, Bauru - SP, Brazil;

e-mail: lucianafd@hotmail.com
}

were deposited in the herbarium of the Universidade Estadual de Feira de Santana.

A. sisalana pulp and juice were collected through mechanical defibration of the leaves. The juice was obtained after filtration three times in filter paper and stored at $4{ }^{\circ} \mathrm{C}$ for use in in vivo tests. For in vitro tests, the juice was dried and frozen. Five concentrations were used in this study: 146.3, 112.5, 86.5, 66.5, 51.1 and $39.3 \mathrm{mg} \cdot \mathrm{mL}^{-1}$, which were tested in triplicate. To validate the results, the same experiment was repeated three times.

Larval cultures (UENO; GONÇALVES, 1998) consisted of $2 \mathrm{~g}$ of feces, $2 \mathrm{~g}$ of sawdust, and $2 \mathrm{~mL}$ of juice. Positive and negative controls were treated with doramectin $\left(0.0625 \mathrm{mg} . \mathrm{mL}^{-1}\right)$ and distilled water, respectively.

Twenty-four racially undefined goats between six and 24 months of age were used. According to eggs per gram (EPG) count, the animals were divided into four groups: Group I (GI) was treated with the juice $\left(0.92 \mathrm{~g} \cdot \mathrm{kg}^{-1}\right)$ for four days; Group II (GII) 
Table 1. Mean ( \pm S.E.) and percent reduction (\%) in the number of eggs of gastrointestinal nematodes of goats treated with the juice of Agave sisalana.

\begin{tabular}{|c|c|c|c|c|c|}
\hline \multirow[t]{3}{*}{ Groups } & \multicolumn{5}{|c|}{ Days of treatment } \\
\hline & \multirow{2}{*}{$\frac{0}{\text { Mean } \pm \text { S.E. }}$} & \multicolumn{2}{|c|}{8} & \multicolumn{2}{|l|}{15} \\
\hline & & Mean \pm S.E. & $\%$ & Mean \pm S.E. & $\%$ \\
\hline GI & $1675 \pm 877^{a}$ & $1958 \pm 1527^{a}$ & 0 & $1250 \pm 346^{a}$ & 0 \\
\hline GII & $1566 \pm 1106^{a}$ & $1975 \pm 1787^{a}$ & 0 & $2162 \pm 1400^{a}$ & 0 \\
\hline GIII & $1658 \pm 1454^{a}$ & $117 \pm 250^{b}$ & 97 & $50 \pm 45^{b}$ & 95 \\
\hline GIV & $2150 \pm 1384^{a}$ & $1675 \pm 1281^{\mathrm{a}}$ & - & $1063 \pm 553^{a}$ & - \\
\hline
\end{tabular}

Letters differing in the same column signify statistical differences $(\mathrm{p}<0.05)$. GI - $0.92 \mathrm{~g} . \mathrm{kg}^{-1} \mathrm{BW} / 4$ days; GII $-0.92 \mathrm{~g} \cdot \mathrm{kg}^{-1} \mathrm{BW} / 8$ days; GIII - Doramectin $\left(200 \mu \mathrm{g} . \mathrm{kg}^{-1}\right.$ BW); GIV - No treatment. was treated with the same dose for eight days; Group III (GIII) was treated with a single dose of doramectin $\left(200 \mathrm{~g} \cdot \mathrm{kg}^{-1}\right)$; and Group IV (GIV) (negative control) was not treated.

The material was collected on Days 0,8 , and 15; and necropsies were performed on Days 8 and 15. At necropsy, immature and adult parasites in the gastrointestinal tract were identified and counted, and they were histopathologically evaluated.

The effectiveness of juice on eggs and larvae of gastrointestinal nematodes in goats was evaluated at different concentrations by testing percent reduction (PR) of eggs or larvae (VIZARD; WALLACE, 1987). The number of larvae was transformed into a decimal logarithm to standardize the data (BOX; COX, 1964). Differences between the results of egg and larval counts (L4 and L5)

Table 2. Mean $\left( \pm\right.$ S.E.) and percent reduction $(\%)$ of the number of gastrointestinal nematode larvae $\left(\mathrm{L}_{4}\right.$ e $\left.\mathrm{L}_{5}\right)$ recovered from goats after treatment with the juice of Agave sisalana.

\begin{tabular}{|c|c|c|c|c|c|c|c|}
\hline \multirow[t]{2}{*}{ Species } & \multicolumn{2}{|l|}{ GI } & \multicolumn{2}{|l|}{ GII } & \multicolumn{2}{|c|}{ GIII } & \multirow{2}{*}{$\begin{array}{c}\text { GIV } \\
\text { Mean } \pm \text { S.E. }\end{array}$} \\
\hline & Mean \pm S.E. & $\%$ & Mean \pm S.E. & $\%$ & Mean \pm S.E. & $\%$ & \\
\hline Haemonchus contortus & $213 \pm 204^{a}$ & 40 & $305 \pm 348^{a}$ & 14 & $48 \pm 71^{\mathrm{b}}$ & 87 & $322 \pm 180^{\mathrm{a}}$ \\
\hline Oesophagostomum columbianum & $34 \pm 23^{\mathrm{a}}$ & 29 & $28 \pm 14^{\mathrm{a}}$ & 32 & $0,2 \pm 0,4^{\mathrm{b}}$ & 80 & $46 \pm 22^{a}$ \\
\hline Trichostrongylus colubriformis & $118 \pm 74^{\mathrm{a}}$ & 0 & $78 \pm 55^{a}$ & 16 & $6 \pm 12^{\mathrm{b}}$ & 83 & $130 \pm 135^{\mathrm{a}}$ \\
\hline Total & $366 \pm 216^{a}$ & 18 & $412 \pm 389^{a}$ & 19 & $54 \pm 68^{b}$ & 90 & $498 \pm 291^{\mathrm{a}}$ \\
\hline
\end{tabular}

Letters differing in the same line signify statistical differences $(\mathrm{p}<0.05)$.

GI - 0.92 g.kg-1 BW/4 days; GII - 0.92 g. $\mathrm{kg}^{-1}$ BW/8 days; GIII - Doramectin (200 $\mu$ g. $\mathrm{kg}^{-1}$ BW); GIV - No treatment.

Table 3. Mean ( \pm S.E.) of hematological parameters of goats treated with the juice of Agave sisalana.

\begin{tabular}{|c|c|c|c|c|c|c|c|c|c|c|c|}
\hline \multirow[t]{3}{*}{ Parameters } & \multicolumn{11}{|c|}{ Groups and days of treatment } \\
\hline & \multicolumn{3}{|c|}{ GI } & \multicolumn{3}{|c|}{ GII } & \multicolumn{3}{|c|}{ GIII } & \multicolumn{2}{|r|}{ GIV } \\
\hline & $\mathbf{0}$ & 8 & 15 & $\mathbf{0}$ & 8 & 15 & $\mathbf{0}$ & 8 & 15 & $\mathbf{0}$ & 15 \\
\hline $\begin{array}{l}\text { Erythrocytes } \\
\left(\times 10^{6} \cdot \mu \mathrm{L}^{-1}\right) \\
(\mathrm{RR}: 8-18)\end{array}$ & $13 \pm 3.4^{\mathrm{ab}}$ & $10 \pm 3^{\mathrm{a}}$ & $9 \pm 1.5^{\mathrm{a}}$ & $13 \pm 2.9^{\mathrm{ab}}$ & $11 \pm 2.2^{\mathrm{ab}}$ & $12 \pm 2.1^{\mathrm{ab}}$ & $15 \pm 3.6^{\mathrm{b}}$ & $14 \pm 3.3^{b}$ & $13 \pm 1.6^{b}$ & $12 \pm 1.2^{\mathrm{a}}$ & $10 \pm 1.1^{\mathrm{a}} 10 \pm 1.7^{\mathrm{ab}}$ \\
\hline $\begin{array}{l}\text { Hematocrit (\%) } \\
\text { (RR: } 22-38)\end{array}$ & $22 \pm 5.1^{\mathrm{a}}$ & $21 \pm 5.7^{a}$ & $21 \pm 6.3^{a}$ & $22 \pm 3.3^{\mathrm{a}}$ & $20 \pm 5^{a}$ & $23 \pm 2.7^{a}$ & $26 \pm 6.1^{a}$ & $26 \pm 4.9^{\mathrm{a}}$ & $26 \pm 4.6^{a}$ & $22 \pm 2.7^{a}$ & $22 \pm 3.3^{a} 21 \pm 3.9^{a}$ \\
\hline $\begin{array}{c}\text { Mean cell } \\
\text { volume }(\mathrm{fL}) \\
(\mathrm{RR}: 16-25)\end{array}$ & $17 \pm 1.9^{\mathrm{a}}$ & $20 \pm 2.8^{\mathrm{a}}$ & $24 \pm 3^{a}$ & $17 \pm 1.4^{\mathrm{a}}$ & $19 \pm 4^{\mathrm{a}}$ & $19 \pm 2.7^{b}$ & $17 \pm 1^{\mathrm{a}}$ & $19 \pm 3.4^{\mathrm{a}}$ & $20 \pm 1.7^{\mathrm{ab}}$ & $19 \pm 1.4^{\mathrm{a}}$ & $21 \pm 2.4^{\mathrm{a}} 21 \pm 0.7^{\mathrm{ab}}$ \\
\hline $\begin{array}{l}\text { Total protein } \\
\quad\left(\text { g. } \mathrm{dL}^{-1}\right) \\
\text { (RR: } 5.3-8.3)\end{array}$ & $7.2 \pm 1.2^{\mathrm{a}}$ & $6.9 \pm 1.4^{\mathrm{a}}$ & $7.5 \pm 1.7^{\mathrm{ab}}$ & $6.9 \pm 0.7^{a}$ & $6.6 \pm 0.9^{a}$ & $7.1 \pm 0.3^{\mathrm{ab}}$ & $7.7 \pm 0.6^{\mathrm{a}}$ & $7.8 \pm 0.6^{\mathrm{a}}$ & $8.1 \pm 0.6^{\mathrm{a}}$ & $7.1 \pm 0.9^{\mathrm{a}}$ & $7 \pm 1.1^{\mathrm{a}} 6,1 \pm 0.8^{\mathrm{b}}$ \\
\hline $\begin{array}{c}\text { Leukocytes } \\
\left(\times 10^{3} \cdot \mu \mathrm{L}^{-1}\right) \\
\left(\mathrm{RR}: 4-13 \times 10^{3}\right)\end{array}$ & $10.3 \pm 3.3^{\mathrm{a}}$ & $9.1 \pm 2.3^{\mathrm{ab}}$ & $6.6 \pm 0.7^{a}$ & $9.9 \pm 2.9^{\mathrm{a}}$ & $8.6 \pm 1.9^{\mathrm{ab}}$ & $7.6 \pm 1.0^{\mathrm{a}}$ & $11.1 \pm 1.7^{\mathrm{a}}$ & $11.9 \pm 3.7^{\mathrm{b}}$ & $6.4 \pm 1.1^{\mathrm{a}}$ & $9.7 \pm 3.4^{\mathrm{a}}$ & $8 \pm 2.4^{\mathrm{a}} 7.6 \pm 1.4^{\mathrm{a}}$ \\
\hline $\begin{array}{c}\text { Segmented } \\
\text { Neutrophils } \\
\left(\times 10^{3} \cdot \mu L^{-1}\right) \\
\left(\text { RR: } 1.2-7.2 \times 10^{3}\right)\end{array}$ & $6.2 \pm 2.6^{\mathrm{a}}$ & $4.2 \pm 1.5^{\mathrm{a}}$ & $1.3 \pm 0.2^{\mathrm{a}}$ & $4.2 \pm 1.5^{\mathrm{a}}$ & $3.5 \pm 1.6^{a}$ & $2.4 \pm 0.4^{\mathrm{b}}$ & $4.9 \pm 0.9^{a}$ & $3.7 \pm 1.6^{\mathrm{a}}$ & $2.1 \pm 0.1^{\mathrm{b}}$ & $4.9 \pm 2.1^{\mathrm{a}}$ & $2.9 \pm 1.2^{\mathrm{a}} 3.2 \pm 0.6^{\mathrm{b}}$ \\
\hline $\begin{array}{l}\text { Lymphocytes } \\
\left(\times 10^{3} \cdot \mu \mathrm{L}^{-1}\right) \\
\left(\mathrm{RR}: 2-9 \times 10^{3}\right)\end{array}$ & $4 \pm 1.2^{\mathrm{a}}$ & $4.6 \pm 1.1^{\mathrm{ab}}$ & $5.3 \pm 0.9^{\mathrm{a}}$ & $5.3 \pm 2.2^{\mathrm{a}}$ & $4.7 \pm 1.9^{\mathrm{ab}}$ & $4.9 \pm 1.3^{\mathrm{a}}$ & $5.8 \pm 1.6^{\mathrm{a}}$ & $7.6 \pm 2.9^{\mathrm{b}}$ & $3.9 \pm 1.1^{\mathrm{a}}$ & $4.6 \pm 1.9^{a}$ & $4.7 \pm 2.2^{\mathrm{a}} 3.9 \pm 1^{\mathrm{a}}$ \\
\hline $\begin{array}{c}\text { Monocytes } \\
\left(\times 10^{3} \cdot \mu \mathrm{L}^{-1}\right) \\
\left(\mathrm{RR}: 0-0.55 \times 10^{3}\right)\end{array}$ & $0.1 \pm 0.1^{\mathrm{a}}$ & $0.1 \pm 0.1^{\mathrm{a}}$ & $0.1 \pm 0.1^{\mathrm{a}}$ & $0.2 \pm 0.2^{\mathrm{a}}$ & $0.1 \pm 0.1^{\mathrm{a}}$ & $0.1 \pm 0.1^{\mathrm{a}}$ & $0.2 \pm 0.1^{\mathrm{a}}$ & $0.1 \pm 0.1^{\mathrm{a}}$ & $0.1 \pm 0.1^{\mathrm{a}}$ & $0.1 \pm 0.1^{\mathrm{a}}$ & $0.1 \pm 0.1^{\mathrm{a}} 0.1 \pm 0.1^{\mathrm{a}}$ \\
\hline $\begin{array}{c}\text { Eosinophils } \\
\left(\times 10^{3} \cdot \mu \mathrm{L}^{-1}\right) \\
\left(\mathrm{RR}: 0.05-0.65 \times 10^{3}\right)\end{array}$ & $0.1 \pm 0.1^{\mathrm{a}}$ & $0.2 \pm 0.1^{\mathrm{a}}$ & $0 \pm 0^{\mathrm{a}}$ & $0.2 \pm 0.1^{\mathrm{a}}$ & $0.4 \pm 0.3^{\mathrm{a}}$ & $0.2 \pm 0.1^{\mathrm{b}}$ & $0.2 \pm 0.2^{\mathrm{a}}$ & $0.5 \pm 0.4^{\mathrm{a}}$ & $0.2 \pm 0.1^{\mathrm{b}}$ & $0.4 \pm 0.7^{\mathrm{a}}$ & $0.2 \pm 0.1^{\mathrm{a}} 0.4 \pm 0.2^{\mathrm{b}}$ \\
\hline
\end{tabular}

Letters differing in the same line signify statistical differences $(\mathrm{p}<0.05)$ between the groups.

GI - 0.92 g. $\mathrm{kg}^{-1}$ BW/4 days; GII - 0.92 g. $\mathrm{kg}^{-1}$ BW/8 days; GIII - Doramectin $\left(200 \mu \mathrm{g} \cdot \mathrm{kg}^{-1}\right.$ BW); GIV - No treatment. 
and hematological parameters were evaluated by the univariate test of variance using the statistical program SPSS (version 15.0).

In vitro tests showed more than $95 \%$ reduction larval counts at concentrations between 86.5 and $146.3 \mathrm{mg} \cdot \mathrm{mL}^{-1}$.

In vivo tests showed no reduction in EPG counts in the animals in GI and GII. GIII, EPG counts were greatly reduced at Day 8 and continued to decrease gradually until the end of the study (Table 1). The reduction in the number of larvae of fourth (L4) and fifth (L5) stage was less than 95\% in GI and GII, and between 80 and 90\% in GIII. Moreover, there was a significant reduction $(\mathrm{p}<0.05)$ of these larvae in GIII compared to other groups (Table 2 ).

The discrepancy between the results of anthelmintic efficacy in vitro and in vivo has been attributed to several factors, including availability and/or concentration of active compounds in the preparation of plant material (HOUNZANGBE-ADOTE et al., 2005) and bioavailability and biotransformation of these compounds in animal body (VANDAMME; ELLIS, 2004). In polygastric animals, ruminal microorganisms can affect active chemical constituents of plants and reduce their bioavailability, and this may have contributed to low anthelmintic efficacy of $A$. sisalana juice found in the present study.

The results presented in Table 3 fall within normal physiological range of each parameter, with the exception of hematocrit, which was below normal on Day 8 in GI and GII and on Day 15 in GI and GIV.

Serum GGT (30-58 IU.L $\left.{ }^{-1}\right)$, ALT (25-77 IU.L $\left.{ }^{-1}\right)$, ALP (10-14 IU.L $\left.\mathrm{L}^{-1}\right)$, urea (36-55 mg.dL $\mathrm{dL}^{-1}$ ) and creatinine $\left(0,9-1,2 \mathrm{mg} \cdot \mathrm{dL}^{-1}\right)$ remained within the normal range throughout the experiment. Body temperature, heart and respiratory rates, and rumen motility remained within the normal range.

The macroscopic changes observed in necropsied animals were consistent with common findings often reported in parasitized animals. These changes included pale mucous membranes, edematous and pale superficial lymph nodes, abomasal edema and hyperemia with mucosal hypertrophy and erosion areas, hemorrhagic enteritis across the small intestine with calcified Oesophagostomum nodules in the small and large intestines. The histological changes in liver biopsies were degenerative in nature with discrete inflammation, cellular edema and steatosis with focal hepatitis in all groups. Acute cellular edema and focal discrete tubular necrosis were found in isolated areas of kidney biopsies from two animals in GI and from one animal in GII.

Oral treatment of goats $A$. sisalana juice did not appear to produce clinically toxic effects on animals. Saponins in general have reduced toxicity when administered orally due to their poor absorption in the gastrointestinal tract (PRICE et al., 1987).

In conclusion, $A$. sisalana juice at the concentrations tested was effective against GNI in goats in in vitro tests; however, the anthelmintic efficacy was markedly reduced in vivo. Studies using higher juice concentrations, or other specific active saponin fractions extracted from the plant are needed to better assess the anthelmintic potential of $A$. sisalana.

\section{Acknowledgments}

We thank the Fundação de Amparo à Pesquisa do Estado da Bahia (FAPESB) and the Pró-Reitoria de Pesquisa e Pós-Graduação (PRPPG) for their financial support for this project.

\section{References}

BOX, G. E. P.; COX, D. R. An analysis of transformations. Journal of the Royal Statistical Society, v. 26, p. 211-243, 1964.

HOUNZANGBE-ADOTE, M. S. et al. In vitro effects of four tropical plants on three life-cycle stages of the parasitic nematode, Haemonchus contortus. Research in Veterinary Science, v. 78, n. 2, p. 155-160, 2005.

PRICE, K. R.; JOHNSON, I. T.; FENWICK, G. R. The chemistry and biological significance of saponins in foods and feedingstuffs. Critical Reviews in Food Science and Nutrition, v. 26, n. 1, p. 27-135, 1987.

UENO, H.; GONÇALVES, P. C. Manual para Diagnóstico das Helmintoses de Ruminantes. Tokyo: JICA, 1998.150 p.

VANDAMME, T. F.; ELLIS, K. J. Issues and challenges in developing ruminal drug delivery systems. Advanced Drug Delivery Reviews, v. 56, n. 10 , p. $1415-1436,2004$.

VIZARD, A. L.; WALLACE, R. J. A simplified faecal egg count reduction test. The Australian Veterinary Journal, v. 64, n. 4, p. 109-111, 1987. 